IIIIIIIIIIIIIIIIIIIIIIIIIIIIIIIIIIII

Original Article

IIIIIIIIIIIIIIIIIIIIIIIIIIIIIIIIIII

\title{
Indoxacarb interaction alters immunotoxic and genotoxic potential of endotoxin
}

\author{
Kaur Sandeep, Chandra S. Mukhopadhyay, Jaspreet S. Arora and Ram S. Sethi* \\ Guru Angad Dev Veterinary and Animal Sciences University, Ludhiana, Punjab, India
}

(Received January 22, 2016; Accepted April 18, 2016)

\begin{abstract}
Indoxacarb is commonly used to effectively control pests, cockroaches, termites, fleas, and houseflies. Although the toxicological profile of indoxacarb had already been well characterized, we examined the possible toxicological interaction with indoxacarb and endotoxin. Male Swiss albino mice aged 8-10 weeks were orally administered indoxacarb dissolved in groundnut oil at $4 \mathrm{mg} /$ $\mathrm{kg} / \mathrm{day}$ and $2 \mathrm{mg} / \mathrm{kg} /$ day for 90 days. On day 91 , five animals from each group were challenged with lipopolysaccharides (LPS) at $80 \mu \mathrm{g} /$ mouse, administered intranasally. Indoxacarb at $4 \mathrm{mg} / \mathrm{kg}$ significantly decreased Total leukocyte count, lymphocytopenia, and neutrophilia. Both doses of indoxacarb combined with LPS resulted in significant lymphocytopenia. Indoxacarb did not produce DNA damage in comet assay, but when combined with LPS, it resulted in a significant increase in tail length, tail moment, and olive moment. The data indicate that indoxacarb at $4 \mathrm{mg} / \mathrm{kg}$ administered orally for 90 days induced immune-response change. Further, both doses of indoxacarb, when combined with LPS, accelerate immunotoxicity and endotoxin-induced DNA damage. () Pesticide Science Society of Japan

Keywords: indoxacarb, genotoxicity, immunotoxicity, lipopolysaccharide, comet assay, mice.
\end{abstract}

\section{Introduction}

The toxic effects of various classes of pesticides on ecosystems are not restricted to an ecological niche but also affect human health due to the persistence and bioaccumulation of toxic pesticide residues in the food chain. ${ }^{1)}$ Intensive pesticide use has lead to resistance to DDT, pyrethroids, and other compounds involving transformation at the site of action, elevating detoxication and metabolism. ${ }^{2)}$ Occupational hazard and accidental or intentional poisonings also pose threats to humans and result in more than one million cases of pesticide toxicity and hundreds of thousands deaths each year globally. ${ }^{3)}$

Indoxacarb is the first marketable pesticide of a recent class known as oxadiazines and is highly competent against a wide range of agricultural pests. ${ }^{4)}$ Indoxacarb was registered in 2000 by the United States Environmental Protection Agency in water dispersible granules (Avaunt ${ }^{\circledR}$ ) and emulsifiable concentrate $\left(\right.$ Steward ${ }^{\circledR}$ ) formulations, mainly for foliar application targeting lepidopteran pests of cotton, rice, apples, pears, sweet corn, lettuce and fruiting vegetables. ${ }^{5)}$ Indoxacarb has more recently been shown to be effective in the control of cockroaches, fire ants, termites, fleas, and houseflies ${ }^{6)}$ and has been commercialized as a gel bait $\left(\operatorname{Advion}^{\circledR}\right)$.

\footnotetext{
* To whom correspondence should be addressed.

E-mail: sethi116@gmail.com

Published online August 2, 2016

(c) Pesticide Science Society of Japan
}

Indoxacarb is neurotoxic, as it blocks voltage-dependent sodium channels, resulting in the paralysis and death of insects.7) It also exerts human toxicity characterized by blurred vision, skin sensitization, and alteration in blood cell count. Further methemoglobinemia occurs after indoxacarb ingestion because its aromatic metabolites can transform into active intermediates that produce methemoglobin. ${ }^{8)}$ Chronic exposure to indoxacarb depletes blood-forming elements in the bone marrow and lymphoid organs in mice and rats due to the formation of metabolite. ${ }^{9)}$ Hemolytic anemia characterized by decreased red blood cells, increases in platelets, and secondary histopathological findings indicate blood breakdown after oral toxicity from indoxacarb in dogs. ${ }^{10)}$ Sub-chronic (28 days) inhalation toxicity of indoxacarb results in the elevation of spleen weight, increased pigmentation, and hematopoiesis in the spleen and hematological changes in rats. ${ }^{11)}$

Lipopolysaccharides (LPSs), among the preeminent components of all Gram-negative bacteria, have been broadly studied as a major factor contributing to the pathogenesis of bacterial infections. They continuously diffuse into the surrounding environment and frequently prevail in organic dust and ambient places. ${ }^{12)}$ LPS induces the synthesis and release of several cytokines, resulting in oxidative stress by the production of several reactive oxygen species from neutrophils and other phagocytic cells. ${ }^{13)}$

LPS resulted in genotoxicity in human peripheral blood mononuclear cells ${ }^{14,15)}$ and in pre-implanting embryonic and uterine cells, ${ }^{16)}$ while there is no report of the genotoxic poten- 
tial of indoxacarb when combined with LPS. The endotoxin/ LPS and pesticide interaction increases the toxicity of various pesticides, ${ }^{17)}$ suggesting that exposure to LPS may amplify the effects of indoxacarb. Hence, we used a mouse model to test the hypothesis that chronic exposure to indoxacarb alone or in combination with LPS results in genotoxicity and immunotoxicity.

\section{Materials and Methods}

\section{Experimental animals}

The experiment was conducted after approval from the Institutional Animal Ethics Committee, Guru Angad Dev Veterinary and Animal Sciences University, Ludhiana, Punjab. Thirty healthy Swiss albino (Mus musculus) male mice aged 8-10 weeks were obtained from LLRUVAS Hisar, Haryana, and maintained under conventional controlled conditions $\left(22 \pm 2^{\circ} \mathrm{C}, 50 \%\right.$ humidity, 12-hr photoperiod) in an animal house for 7 days to allow acclimation prior to the experiments. All mice were clinically evaluated before the start of the experiment and were found to be healthy. The animals were provided food and drinking water ad libitum.

\section{Chemicals}

Indoxacarb with a purity level of 99.9\%, LPS from Escherichia coli, and ethidium bromide were obtained from Sigma-Aldrich, Bangalore. Dulbecco's phosphate-buffered saline, normal melting point agarose, Triton X-100, and dimethyl sulphoxide were procured from SRL Diagnostics, India. Low melting point agarose was obtained from Invitrogen, India.

\section{Doses}

Indoxacarb doses $(2 \mathrm{mg} / \mathrm{kg} /$ day and $4 \mathrm{mg} / \mathrm{kg} /$ day $)$ used in the present study are above the no observed adverse effect level (NOAEL), i.e., $1 \mathrm{mg} / \mathrm{kg} /$ bodyweight.

\section{Experimental procedure}

Mice were randomly divided into 2 treatments and 1 control group ( $n=10$ for each group). Treatment groups were orally administered indoxacarb dissolved in groundnut oil at $4 \mathrm{mg} / \mathrm{kg} /$ bw (IC1 group) and $2 \mathrm{mg} / \mathrm{kg} / \mathrm{bw}$ (IC2 group) for 90 days. The control group was administered groundnut oil for 90 days. At the end of the experiment, 5 animals from each group were challenged with LPS at $80 \mu \mathrm{L} /$ animal by intranasal route. The remaining animals were challenged with normal saline solution (NSS) at $80 \mu \mathrm{L} /$ mouse by the same route.

\section{Collection of blood}

After $9 \mathrm{hr}$ of LPS/NSS challenge, all of the animals were anaesthetized by intraperitoneal administration of xylazine and ketamine $(0.1 \mu \mathrm{L} / 10 \mathrm{~g}$ of body weight $)$ and humanely sacrificed. Blood was collected in EDTA-coated tuberculin vials and processed for total leukocyte count, differential leukocyte count, and comet assay on the same day.

\section{Total leukocyte count (TLC) analysis}

Twenty microliters of the blood was mixed properly with $380 \mu \mathrm{L}$ of the white blood cell diluting fluid in a glass vial. Cells were counted in 4 squares of haemocytometer chambers under $\times 40$ magnification. TLC was calculated by the formula given below:

$$
\begin{aligned}
T L C & (/ \mu \mathrm{L}) \\
= & (\text { Average of cells } \times \text { Correction for dilution }) / \\
& (\text { No. of squares counted } \times \text { Volume of one square })
\end{aligned}
$$

\section{Differential leukocyte count (DLC) analysis}

A drop of blood was used to make a clear blood smear with another slide, keeping it at an angle of $45^{\circ}$. The smear was air-dried and stained with Leishman's stain. After $30-45 \mathrm{sec}$, a buffer was added to the slides and slides were kept at room temperature for 10-12 min. Slides were washed under running tap water and were kept aside to dry. The cells were counted under a microscope at $\times 40$ and expressed in percentage.

\section{Comet assay}

Alkaline conditions were used in the procedure, substantially increasing its specificity and reproducibility as described by Singh and his coworkers. ${ }^{18)}$ Briefly, slides were pre-coated with $1 \%$ normal melting point agarose, and $5 \mu \mathrm{L}$ of whole blood along with $95 \mu \mathrm{L}$ of low melting point agarose $(0.5 \%)$ was placed on the slide at $37^{\circ} \mathrm{C}$. Slides were slip covered and refrigerated at $4^{\circ} \mathrm{C}$ for $5-10 \mathrm{~min}$. Coverslips were removed, and slides were immersed in a freshly prepared lysing solution $(89 \mathrm{~mL}$ of lysis stock solution: (2.5 M NaCl, $100 \mathrm{mM}$ EDTA, $10 \mathrm{mM}$ Tris, $\mathrm{pH} 10$ adjusted with $\mathrm{NaOH}, 1 \%$ of Triton X-100, and $10 \%$ of DMSO) at $4^{\circ} \mathrm{C}$ for $1 \mathrm{hr}$ in the dark. Slides were placed on an electrophoresis chamber filled with buffer $\mathrm{pH}>13(300 \mathrm{mM} \mathrm{NaOH}$ and $1 \mathrm{mM}$ EDTA, prepared with a stock solution of $10 \mathrm{~N} \mathrm{NaOH}$ and $200 \mathrm{mM}$ EDTA, $\mathrm{pH} \mathrm{10}$ ) at $4^{\circ} \mathrm{C}$ for $30 \mathrm{~min}$ for DNA denaturation. Electrophoresis was performed at $24 \mathrm{~V}$ and $300 \mathrm{~mA}(1.25 \mathrm{~V} /$ $\mathrm{cm})$. Slides were then neutralized with buffer pH $7.5(0.4 \mathrm{M}$ Tris- $\mathrm{HCl}$ ) during 3 cycles of $5 \mathrm{~min}$ each, air-dried, stained with ethidium bromide $(20 \mu \mathrm{g} / \mathrm{mL})$, and slip covered.

\section{Quantification of slides}

The slides were examined under a fluorescence microscope equipped with an excitation filter of $420-490 \mathrm{~nm}$ and a barrier filter of $520 \mathrm{~nm}$ at 10 and $\times 40$ magnifications. One hundred cells per animal were examined with the help of Open Comet 1.3, ImageJ $1.47 \mathrm{v}$, Micro-Manager 1.4.13, and Java 1.6.0. ${ }^{19)}$

\section{Statistical analysis}

TLC and DLC results were presented as mean and standard error and compared by one-way analysis of variance following Tukey's test at a $p<0.05$ level of significance. A simple correlation between the parameters for each of the treatment groups was calculated, and the significance of correlation was determined using the Bonferroni correction. The results were compared using a general linear model and post hoc tests for tail pa- 
rameters at a $p<0.05$ level of significance. The correlation between the various comet parameters was graphically represented by a heat map using a WGCNA package of the R program.

\section{Results}

1. Total leucocyte count (TLC) and differential leukocyte count $(D L C)$

The LPS challenge resulted in a significant increase $(p<0.05)$ in the TLC of blood (Table 1) as compared to the control; however, there was a significant decrease $(p<0.05)$ in TLC following indoxacarb treatment at $4 \mathrm{mg} / \mathrm{kg}$ as compared to the control and LPS. Further, indoxacarb at $4 \mathrm{mg} / \mathrm{kg}$, when combined with LPS, resulted in a significant increase $(p<0.05)$ in TLC as compared to indoxacarb at $4 \mathrm{mg}$ or LPS individually. Indoxacarb at $2 \mathrm{mg} /$ $\mathrm{kg}$ alone did not alter TLC significantly as compared to control and to indoxacarb at $4 \mathrm{mg} / \mathrm{kg}$. However, indoxacarb at $2 \mathrm{mg} / \mathrm{kg}$ in combination with LPS showed a significant decrease $(p<0.05)$ in TLC as compared to LPS but did not differ from indoxacarb at $2 \mathrm{mg} / \mathrm{kg}$ alone.

Analysis of the DLC of blood showed that LPS and indoxacarb at $4 \mathrm{mg} / \mathrm{kg}$ individually showed a significant increase $(p<0.05)$ in the neutrophil count and a significant decrease $(p<0.05)$ in the lymphocyte count as compared to the control (Table 1). Indoxacarb at $4 \mathrm{mg} / \mathrm{kg}$, when combined with LPS, resulted in a further, significant increase $(p<0.05)$ in the neutrophil count and a significant decrease $(p<0.05)$ in the lympho-

Table 1. Total leucocyte count and differential leucocyte count of blood following exposure to indoxacarb with and without LPS.

\begin{tabular}{|c|c|c|c|c|c|c|}
\hline & Control & LPS & IC $4 \mathrm{mg}$ & IC 4 mg+LPS & IC $2 \mathrm{mg}$ & IC $2 \mathrm{mg}+\mathrm{LPS}$ \\
\hline $\mathrm{TLC}\left(\times 10^{3}\right)$ & $3.76^{\mathrm{a}} \pm 3.1$ & $6.94^{\mathrm{b}} \pm 4.4$ & $2.34^{\mathrm{cd}} \pm 2.4$ & $4.96^{\mathrm{e}} \pm 1.4$ & $2.85^{\mathrm{ad}} \pm 3.0$ & $4.20^{\mathrm{ae}} \pm 3.3$ \\
\hline Neutrophils (\%) & $33.2^{\mathrm{a}} \pm 2.5$ & $50.2^{\mathrm{b}} \pm 2.6$ & $46.8^{\mathrm{b}} \pm 2.4$ & $61.8^{\mathrm{c}} \pm 2.1$ & $32.6^{\mathrm{a}} \pm 2.2$ & $52.8^{b c} \pm 2.4$ \\
\hline Lymphocytes (\%) & $61.2^{\mathrm{a}} \pm 2.5$ & $48.4^{\mathrm{b}} \pm 2.6$ & $47.2^{\mathrm{b}} \pm 1.3$ & $33.2^{\mathrm{d}} \pm 1.8$ & $56.2^{\mathrm{ab}} \pm 4.1$ & $44.4^{\mathrm{cd}} \pm 2.7$ \\
\hline
\end{tabular}

Values are expressed as Mean \pm SE. Different letters followed significant difference at $p<0.05$.
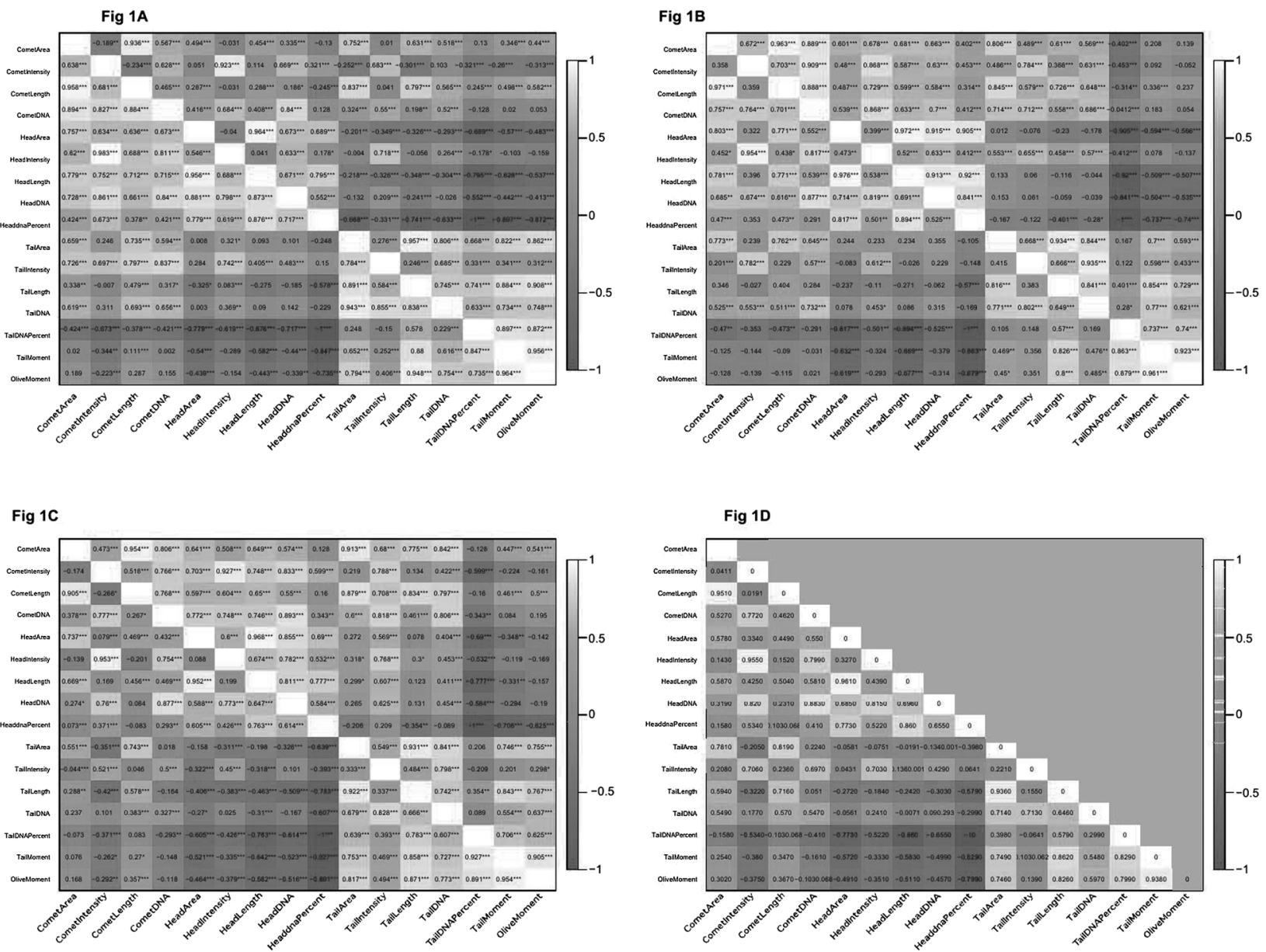

Fig. 1. Heat maps representing correlation coefficient between control and LPS (A) indoxacarb at $4 \mathrm{mg} / \mathrm{kg}$ with and without LPS (B) indoxacarb at $2 \mathrm{mg} /$ $\mathrm{kg}$ with and without LPS (C) and overall groups (D) at $p<0.05^{*}, p<0.01 * *$ and $p<0.001^{* * *}$. 
cyte count as compared to LPS or indoxacarb at $4 \mathrm{mg} / \mathrm{kg}$.

Indoxacarb at $2 \mathrm{mg} / \mathrm{kg}$ alone did not alter the neutrophil or lymphocyte count significantly as compared to the control. However, when combined with LPS, there was a significant decrease $(p<0.05)$ in the lymphocyte count as compared to LPS, the control, and indoxacarb at $2 \mathrm{mg} / \mathrm{kg}$ alone. A comparison of both treatments revealed that indoxacarb at $4 \mathrm{mg}$ was more potent to cause a significant decrease in TLC, along with neutrophilia and lymphocytopenia. Both doses combined with LPS resulted in significant lymphocytopenia as compared to the control, individual dose, and LPS groups.

\section{Comet assay}

Since intact DNA (head) moves at a slower rate and tail parameters are a direct measure of DNA damage, tail parameters were used for the evaluation of DNA damage. Further tail parameters (tail area, intensity, length, DNA, and DNA\%) showed a negative correlation with head parameters (head area, intensity, length, DNA, and head DNA\%) in all of the groups (data not shown). There was a significantly strong positive correlation of tail length with tail moment $(r=0.884, p<0.001)$ and olive moment $(r=0.908, p<0.001)$ between the control and LPS (Fig. 1). Further, indoxacarb at $4 \mathrm{mg}$ with/without LPS showed a significant positive correlation of tail length with tail moment $(r=0.854$, $p<0.001)$ and olive moment $(r=0.729, p<0.001)$. Similarly, indoxacarb at $2 \mathrm{mg}$ alone and with LPS showed a significant correlation of tail length with tail moment $(r=0.843, p<0.001)$ and

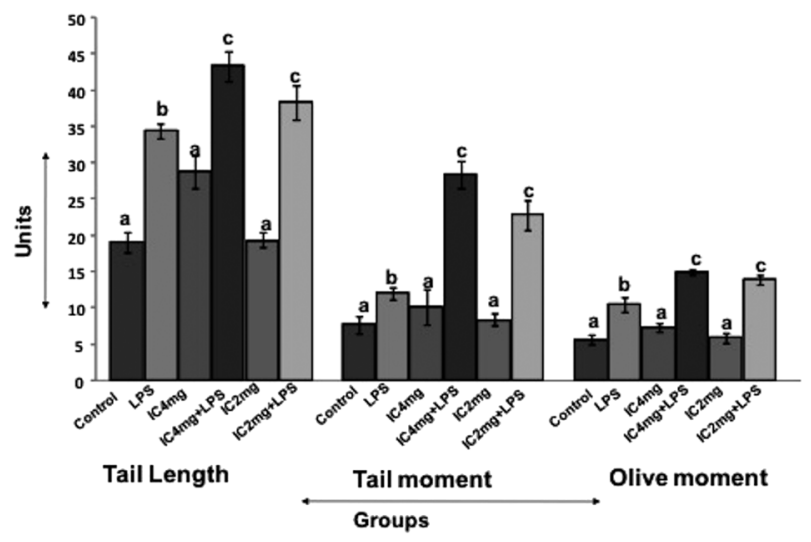

Fig. 2. Comet parameters viz. tail length $(\mu \mathrm{m})$, tail moment and olive moment of whole blood following exposure to indoxacarb with and without LPS. Values are expressed as Mean \pm SEM. olive moment $(r=0.767, p<0.001)$.

LPS resulted in a significant increase $(p<0.05)$ in tail length, tail moment, and olive moment as compared to the control (Fig. 2; Table 2). Indoxacarb treatment at $4 \mathrm{mg} / \mathrm{kg}$ did not induce a significant increase in all tail parameters. However, indoxacarb at $4 \mathrm{mg} / \mathrm{kg}$ combined with LPS resulted in a significant increase $(p<0.05)$ in tail length, tail moment, and olive moment as compared to the control, LPS, or indoxacarb at $4 \mathrm{mg} / \mathrm{kg}$ groups (Fig. 2; Table 2). Similar results were observed with indoxacarb at $2 \mathrm{mg} / \mathrm{kg}$. Further, the distributional characteristics of a group of scores as well as the level of the scores in all of the comet tail parameters showed less than a quartile of olive and tail moment in the control group as compared to other groups (Fig. 3) except for the tail length parameter, which lay in the 25th percentile in the control group. Indoxacarb at both doses combined with LPS showed a maximum divergence in data that lay in the interquartile range, i.e, the 25 th to 75 th percentile.

\section{Discussion}

Indoxacarb blocks voltage-dependent sodium channels ${ }^{20)}$ and produces dynamic modulating actions on nicotinic acetylcholine receptors (nAChRs). ${ }^{21)}$ These receptors could be one of the primary target sites of indoxacarb in mammals. Indoxacarb residues on a dog's coat can be directly transferred to humans in significant amounts, implying that humans have the highest risk of exposure. ${ }^{22)}$ This is the first data on the genotoxic and immunotoxic potential of indoxacarb following its chronic exposure combined with LPS/endotoxins.

Blood findings are important for the determination of various systemic functions and the health of animals under various environmental conditions and for the diagnosis of chemically induced hemolysis. ${ }^{23)}$ LPS resulted in a significant increase in TLC, along with lymphocytopenia and neutrophilia, as observed previously in rats at $10,15,20$, and $25 \mu \mathrm{g} / \mathrm{rat}^{24)}$ and at $2 \mathrm{ng} / \mathrm{kg}$ in mice and humans. ${ }^{25)}$ Indoxacarb at $4 \mathrm{mg} / \mathrm{kg}$ showed a significant decrease in TLC, along with lymphocytopenia or neutrophilia. In contrast, indoxacarb at $5 \mathrm{mg} / \mathrm{kg}$ did not show any lymphocytopenia or neutrophilia in non-rodents or dogs. ${ }^{10)}$ However, the acute toxicity of indoxacarb at a dose of $500 \mathrm{mg} / \mathrm{kg}$ causes significant lymphocytopenia (65.5 to $60.6 \%$ ) and neutrophilia (30.5 to $35.5 \%$ ) in mice and rats. ${ }^{26)}$ Pyrethriod administration also produces significant leucopenia $(p<0.05)$ at $40 \mathrm{mg} / \mathrm{kg}$ on day $90 .{ }^{27,28)}$ Indoxacarb adversely affects bone marrow, resulting in methemoglobinemia and alterations in blood cell count. ${ }^{29)}$

Table 2. Comet parameters viz. tail length $(\mu \mathrm{m})$, tail moment and olive moment of whole blood following exposure to indoxacarb with and without LPS.

\begin{tabular}{lcccccc}
\hline & Control & LPS & IC $4 \mathrm{mg}$ & IC $4 \mathrm{mg}+\mathrm{LPS}$ & IC $2 \mathrm{mg}$ & IC $2 \mathrm{mg}+\mathrm{LPS}$ \\
\hline Tail length $(\mu \mathrm{m})$ & $19.03^{\mathrm{a}} \pm 1.3$ & $34.46^{\mathrm{b}} \pm 0.9$ & $28.80^{\mathrm{a}} \pm 2.2$ & $43.29^{\mathrm{c}} \pm 2.0$ & $19.36^{\mathrm{a}} \pm 1.0$ & $38.36^{\mathrm{c}} \pm 2.3$ \\
Tail moment & $7.81^{\mathrm{a}} \pm 1.1$ & $12.03^{\mathrm{b}} \pm 0.8$ & $10.23^{\mathrm{a}} \pm 2.4$ & $28.48^{\mathrm{c}} \pm 1.8$ & $8.43^{\mathrm{a}} \pm 0.8$ & $22.83^{\mathrm{c}} \pm 1.9$ \\
Olive moment & $5.71^{\mathrm{a}} \pm 0.7$ & $10.53^{\mathrm{b}} \pm 0.9$ & $7.38^{\mathrm{a}} \pm 0.5$ & $14.95^{\mathrm{c}} \pm 0.3$ & $5.93^{\mathrm{a}} \pm 0.6$ & $13.97^{\mathrm{c}} \pm 0.6$ \\
\hline
\end{tabular}

Values are expressed as Mean \pm SE. Different letters followed significant difference at $p<0.05$. 


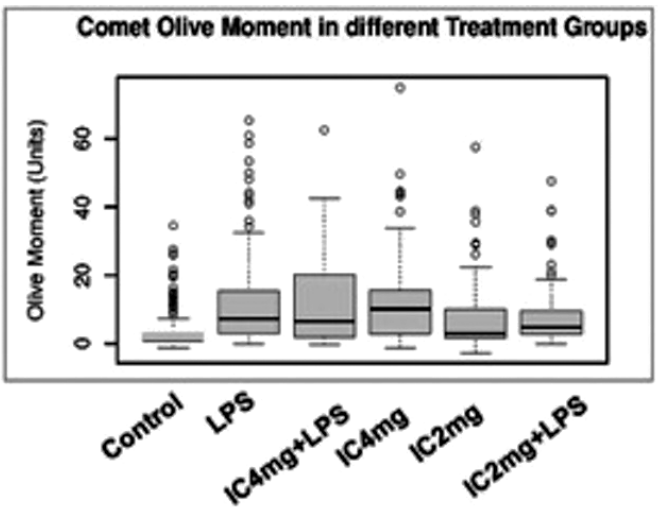

Comet-tail Length in different Treatment Groups

Comet-tail Moment in different Treatment Groups
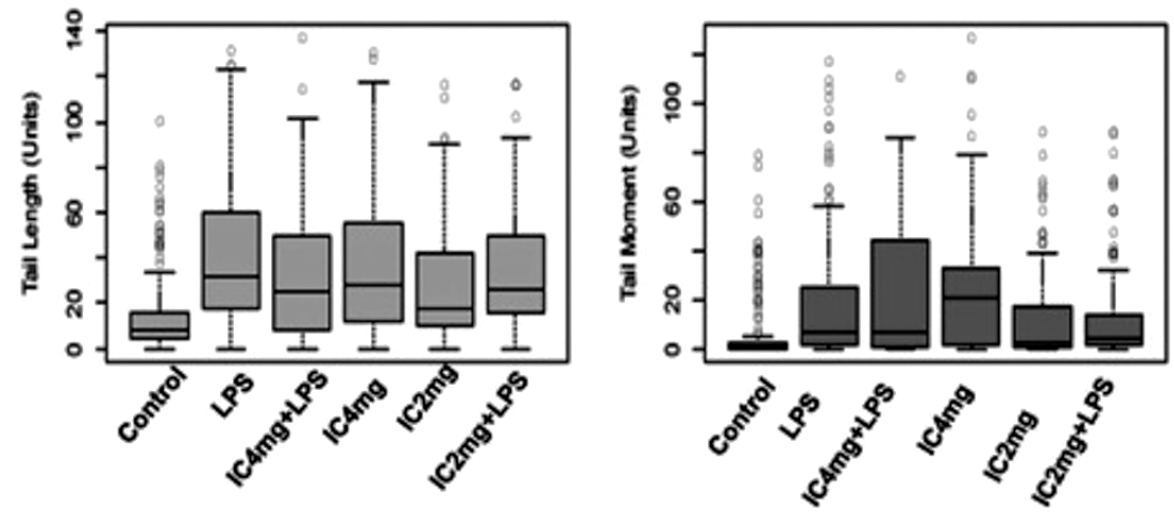

Fig. 3. Box plots graphically representing the data distributions for tail length, tail moment and olive moment. Middle black line denotes the median value, both the edges of each box signify 25th and 75th percentiles and the whiskers protruding out on both side of each box indicate the 2.5th and 97.5th percentiles, respectively. The outliers are evident as grey colored circles outside of the whisker boundaries.

Indoxacarb at both doses, combined with LPS, resulted in significant lymphocytopenia as compared to the control, and LPS suggesting that LPS is a confounding factor for immunotoxicity when combined with both doses of indoxacarb.

Pesticides have been considered potential chemical mutagens, and genetic damage in human populations correlates with the level of exposures to pesticides. ${ }^{30)}$ A comet assay is a valuable tool in the field of genetic toxicology $\mathrm{y}^{31,32)}$ to detect damaged DNA/genotoxicity. ${ }^{33,34)}$ The comet tail moment, tail DNA\%, and tail length are the most frequently used descriptors to predict DNA damage. ${ }^{18,35,36)}$

LPS resulted in a significant increase in tail moment, tail DNA\%, and tail length and there was a significant positive correlation of tail length with tail moment $(r=0.884, p<0.001)$ and olive moment ( $r=0.908, p<0.001$ ), indicating that LPS is genotoxic. LPS at $1 \mathrm{mg} / \mathrm{kg} / \mathrm{bw}$ intraperitonally induces $33 \%$ increase in damage of DNA lymphocyte accompanied by a higher tail length of $6.911 \mu \mathrm{m}$ in male rats. ${ }^{37)}$ Phenothrin exposure causes a significant DNA damage in human peripheral blood lymphocytes (tail moment: $r=0.959, p<0.01$; tail length: $r=0.957$, $p<0.01){ }^{38)}$ The lymphocytopenia following the LPS challenge in the present study may be due to lymphocyte DNA damage.

Indoxacarb did not show any genotoxic potential at either dose. However, when combined with LPS, it resulted in a significant DNA damage as compared to an individual dose of indoxacarb or LPS, suggesting that indoxacarb accelerates endotoxin-induced genotoxicity. Pesticides cause genotoxic effects in directly and indirectly exposed non-target organisms. ${ }^{39,40)}$ Genotoxicity has been observed following exposure to cypermethrin, dichlorvos, and pendimethalin (pyrethroids) in Chinese hamster ovary $(\mathrm{CHO})$ cells $^{41)}$; pyrethroids in rodent bone marrow, ${ }^{42)}$ human peripheral lymphocyte cultures, ${ }^{43)}$ and aquatic organisms ${ }^{44)}$; and phenothrin in both human peripheral blood lymphocytes, and cultured hepatocytes. ${ }^{38)}$

The control group showed marginally higher values for the minimum quantiles than the exposed group for all parameters, which is a common feature in the quantile dispersion graphs in biomonitoring studies. ${ }^{45)}$ The maximum quantile values for the exposed groups (LPS and/or indoxacarb) are mostly higher than those for the control group. Quantification of DNA damage by comet assay is not normally distributed; however, the mean or median values for 25-100 comets lie in 75th percentile values. $^{35)}$ There was less divergence in the control group than in other groups, while most of the values lie in the 25th to 75 th percentile in indoxacarb (both doses) alone or in combination with LPS, indicating that endotoxins along with pesticides exert 
a DNA-damaging effect.

Indoxacarb is a relatively new pesticide, so there are few reports on its adverse effects. Our study does not explore the mechanism behind indoxacarb-induced lymphocytopenia and DNA damage; however, indoxacarb may act as stressor agent, causing release of glucocorticoids ${ }^{26)}$ and/or $\mathrm{ACTH},{ }^{46)}$ resulting in lymphocytopenia and neutrophilia. The data taken together indicate direct or indirect immunotoxicity and genotoxicity due to combined exposure to indoxacarb and LPS, suggesting that indoxacarb may potentiate endoxin-induced immunotoxicity and genotoxicity.

\section{Conclusions}

We conclude that chronic exposure to indoxacarb at $4 \mathrm{mg}$ / $\mathrm{kg}$ orally for 90 days results in immunotoxicity and both doses ( $4 \mathrm{mg} / \mathrm{kg}$ and $2 \mathrm{mg} / \mathrm{kg}$ ) of indoxacarb combined with LPS potentiate endotoxin-induced DNA damage with increased immunotoxicity.

\section{Acknowledgements}

The authors thankfully acknowledge Dr Satyavan Rampal (Professor) and Dr. Suresh Kumar Sharma (Professor cum Head), Department of Veterinary Pharmacology and Toxicology, GADVASU for providing technical support and the required facilities.

\section{References}

1) V. S. Houk: Mutat. Res. 277, 91-138 (1992).

2) J. R. Bloomquist: Rev. Pestic. Toxicol. 2, 185-230 (1993).

3) R. L. Langley and S. A. Mort: J. Agromed. 17, 300-315 (2012).

4) J. S. Park, H. Kim, S. W. Lee and J. H. Min: Clin. Toxicol. 49, 744-746 (2011).

5) S. F. McCann, G. D. Annis, R. Shapiro, D. W. Piotrowski, G. P. Lahm, J. K. Long, K. C. Lee, M. M. Hughes, B. J. Myers, S. M. Griswold, B. M. Reeves, R. W. March, P. L. Sharpe, P. Lowder, W. E. Barnette and K. D. Wing: Pest Manag. Sci. 57, 153-164 (2001).

6) J. C. Anikwe, F. A. Adetoro, J. A. Anogwih, W. A. Makanjuola, K. A. Kemabonta and K. L. Akinwand: Niger. J. Econ. Entomol. 107, 16391642 (2014).

7) K. D. Wing, M. Sacher, Y. Kagaya, Y. Tsurubuchi, L. Mulderig, M. Connair and M. Schnee: Crop Prot. 19, 537-545 (2000).

8) R. Chhabra, I. Singh, M. Tandon and R. Bubu: Ind. J. Anaesth. 54, 239-241 (2010).

9) U.S. EPA: Factsheet: Indoxacarb. Office of Prevention, Pesticides and Toxic Substances, Washington D.C., 2000.

10) California Environmental Protection Agency. Summary of Toxicology Data: Indoxacarb (2004).

11) U.S. EPA: Indoxacarb: Pesticide Tolerance In: Office of Prevention Pesticides and Toxic Substances (ed).: Federal Registrar, EPAHQOPP-2005-0149; FRL-8137-8, 37633-37641(2007).

12) S. I. Dikalov, A. E. Dikalova and R. P. Mason: Arch. Biochem. Biophys. 402, 218-226 (2002).

13) M. S. Harsoliya, J. K. Pathan, N. Khan, V. M. Patel and S. Vyas: Webmed Cent. Toxicol. 2, WMC001696 (2011).

14) E. Sewerynek, G. G. Ortiz, R. J. Reiter, M. I. Pablos, D. Melchiorri and W. M. U. Daniels: Mol. Cell. Endocrinol. 117, 183-188 (1996).

15) I. L. Glukhov, N. P. Sirota and E. A. Kuznetsova: Bull. Exp. Biol. Med. 146, 301-303 (2008).
16) Y. K. Jaiswal, M. K. Jaiswal, V. Agrawal and M. M. Chaturvedi: Fertil. Steril. 91(Suppl), 2095-2103 (2009).

17) P. Duramad, I. B. Tager, J. Leikauf, B. Eskenazi and N. T. Holland: J. Appl. Toxicol. 26, 458-465 (2006).

18) N. P. Singh, M. T. McCoy, R. R. Tice and E. L. Schneider: Exp. Cell Res. 175, 184-191 (1988).

19) B. M. Gyori, G. Venkatachalam, P. S. Thiagarajan, D. Hsu and M. V. Clement: Redox Biol 2, 457-465 (2014).

20) B. Lapied, F. Grolleau and D. B. Satelle: Br. J. Pharmacol. 132, 587595 (2001).

21) X. Zhao, K. Nagata, W. Marszalec, J. Z. Yeh and T. Narahashi: Neurotoxicology 20, 561-570 (1999).

22) H. Litchfield, R. C. Gupta, R. B. Doss, S. D. Bland and T. D. Canerdy: J. Vet. Sci. Technol. 6, 218, doi:10.4172/2157-7579.1000218 (2015).

23) M. Atamanalp and T. Yanik: Turk. J. Vet. Anim. Sci. 27, 1213-1217 (2003).

24) T. R. Ulich, J. del Castillo, R. X. Ni and N. Bikhazi: J. Leukoc. Biol. 45, 546-557 (1989).

25) S. Copeland, H. S. Warren, S. F. Lowry, S. E. Calvano and D. Remick; Inflammation and the Host Response to Injury Investigators: Clin. Diagn. Lab. Immunol. 12, 60-67 (2005).

26) S. P. Shit, R. S. Panghal, V. Kumar and R. D. Rana: Haryana Vet. 47, 49-51 (2008).

27) C. Varshneya, T. Singh, L. D. Sharma, H. S. Bahg and S. K. Garg: Indian J. Physiol. Pharmacol. 36, 123-126 (1992).

28) C. Suwanchaichinda, P. Khamkong, L. Worasuttayangkurn and J. Satayavivad: Environ. Toxicol. Pharmacol. 20, 77-82 (2005).

29) K. Jin: Clin. Toxicol. 50, 227 (2012).

30) C. Bolognesi: Mutat. Res. 543, 251-272 (2003).

31) C. Betti, R. Barale and B. L. Pool-Zobel: Environ. Mol. Mutagen. 22, 172-180 (1993).

32) R. R. Tice, P. W. Andrews and N. P. Singh: Basic Life Sci. 53, 291-301 (1990).

33) N. Avishai, C. Rainowits, E. Moiseeva and B. Rinkevich: Mutat. Res. 518, 21-37 (2002).

34) R. F. Lee and S. Steinert: Mutat. Res. 544, 43-64 (2003).

35) P. L. Olive and J. P. Banath: Nat. Protoc. 1, 23-29 (2006).

36) M. De Boeck, N. Touil, G. De Visscher, P. A. Vande and M. KirschVolders: Mutat. Res. 469, 181-197 (2000).

37) N. I. Zaki, W. A. Hassan and L. A. Hassanin: J. Drug Res. Egypt 28, 69-79 (2007)

38) K. Nagy, G. Rácz, T. Matsumoto, R. Ádány and B. Ádám: Mutat. Res. Genet. Toxicol. Environ. Mutagen. 770, 1-5 (2014).

39) M. Nehéz, P. Boros, A. Ferke, J. Mohos, M. Palotás, G. Vetró, M. Zimányi and I. Dési: Regul. Toxicol. Pharmacol. 8, 37-44 (1988).

40) M. Börzsönyi, G. Török, A. Pintér and A. Surján: IARC Sci. Publ. 56, 465-486 (1984).

41) S. Patel, M. Bajpayee, A. K. Pandey, D. Parmar and A. Dhawan: Toxicol. In Vitro 21, 1409-1418 (2007).

42) D. K. Agarwal, L. K. S. Chauhan, S. K. Gupta and V. Sundararaman: Mutat. Res. 311, 133-138 (1994).

43) J. Surralles, E. Carbonell, M. Puig, N. Xamena, A. Creus and R. Marcos: Toxicol. Lett. 54, 151-155 (1990).

44) M. A. Campana, A. M. Panzer, V. J. Moreno and F. N. Dulout: Mutat. Res. 438, 155-161 (1999).

45) E. Lee, E. Oh, J. Lee, D. Sul and J. Lee: Toxicol. Sci. 81, 121-132 (2004).

46) R. C. Haynes Jr. and F. Murad: "Goodman and Gilman's The Pharmacological basis of Therapeutics," 6th Ed., MacMillan Publishing Co. Inc., New York, pp. 1466-1498, 1980. 